\title{
Responsiveness in the Supply Chain: A Possible Decision-Driver for Location of New Subsidiaries?
}

\author{
Ronald Tavares Pires da Silva \\ UNISINOS / UNEMAT \\ olhaolha@olhaolha.com.br \\ Cristiane Biazzin Villar \\ FGV-EAESP \\ cristianevillar@hotmail.com \\ $\underset{\text { JanV-EAESP }}{\text { Jaína Siegler }}$ \\ janaina.siegler@gmail.com
}

\begin{abstract}
This study explores possible new drivers that may be integrated into the decision-making models for establishing the location of subsidiaries. More precisely, it seeks to answer the following research question: "Does the degree of responsiveness in the supply chain influence decisions regarding the location of multinational subsidiaries?" Based on the theoretical approaches of the Uppsala School, the Eclectic Paradigm and RBV, this research analyzes the case of a large multinational in the agribusiness sector, aiming to explore the recent decision-drivers for the location of new subsidiaries and the influence of the current competitive market in this context.
\end{abstract}

Keywords: internationalization; operations strategy; responsiveness; location of subsidiaries; case study. 


\section{INTRODUCTION}

The operations strategies adopted by organizations with the aim of attending clients in a responsive manner have been the target of constant interest in academia and in organizations themselves (MATSON, 1999). In this context, operations strategies have been highlighted in examining their impacts, whether on local or international business decisions.

On the one hand, the literature of internationalization has appraised, among other points, the driving factors that influence the decision regarding the location of multinational subsidiaries. On the other, with the emergence of new internationalization models for multinational companies based in countries emerging as new economic powers, it is brought into question as to whether the paradigms, which have already been established, fully match the new models that have been configured, as well as the new demands of the market itself have established in the face of the increasingly competitive global environment.

To this propulsion generated by the activities of international operations and the increase in international business by multinational companies, one can add countries with quite outstanding emerging economies, such as those of Latin America, and, more recently, those of the African continent (UNCTAD, 2010). The IMF (2011) estimates indicated a trend towards deceleration common to almost all the regions of the world, with the sole exception of Africa. According to IMF forecasts, the regions of the Middle East and North Africa, will grow 3.2\% in 2012, whereas the GDP of sub-Saharan Africa will increase by $5.5 \%$, in both cases, higher rates than those recorded in 2011. The investment on the African continent from China alone rose from US\$ 49.2 million in 1990 to US\$ 1.595 billion in 2005 (UNCTAD, 2010).

The aspects that influence the decision to establish new subsidiaries may vary among companies and contexts. According to the Uppsala theory, behavioral and cultural aspects are the determinants of the process (JOHANSON and PAUL, 1975). From the economic point of view, known as the Eclectic Paradigm (DUNNING, 1980, 1988 and 1993), it is believed that internationalization decisions are associated to structural questions, those of location, all based on the possibilities of asset transfer across national borders.
Other authors argue the importance of taking into consideration difficulties that may exist in the internationalization processes, such as operational costs abroad, specific disadvantages in being foreigners, the fact subsidiaries tend to present worse results than in their domestic markets, allied to a greater probability of them being closed, not to mention frequent litigation in foreign jurisdictions (CUERVO-CAZURRA, 2008). Although both theories support locational decisions regarding multinational subsidiaries, it is worth stressing the need for a new configuration for global production systems, especially for emerging countries, as defended by Fleury and Fleury (2009), and here a gap emerges: Will these theories suffice when taking locational decisions regarding international operations? According to Kleindorfer (1993), among the main concerns of the risk management area in the supply field is the definition of supply chains in relation to the structuring of products, geography (location).

Thus, this work seeks to answer thefollowing research question: "Does the degree of responsiveness in the supply chain influence decisions regarding the location of multinational subsidia-ries?" Based on the theories of the Uppsala School, Eclectic Paradigm and RBV, this research will analyze a case study of a major multinational in the agribusiness sector, the aim being to explore the recent decisiondrivers regarding the location of new subsidiaries.

For this purpose, this work is structured in the following manner: initially it briefly presents a discussion about responsiveness in supply chain management and the role of international operations strategy followed by key theoretical approaches towards company internationalization. Next, there is a presentation of RBV perspectives. Afterwards, the research methodology is detailed, followed by discussion of the case, and the work ends with concluding remarks.

\section{THEORETHICAL B ACKGROUND}

In this section we discuss topics of responsiveness in SCM and International Operations Strategy, considering the main Driving-factors in the decisionmaking process for subsidiary location and present some Internationalization strategy theories taking Uppsala School and Resource Based View (RBV) in consideration. 


\subsection{The role of Responsiveness in Supply Chain Management and International Operations Strategy}

"Soybean prices touched a six-week low, pressured by China's latest cancellation of a U.S. soybean purchase and by a favorable weather outlook for crops in South America. (...) A favorable weather outlook for crops in South America is also weighing on soybean prices. Companies that rely on soybean supplies, such as food processors and livestock companies, are counting on Brazil, the world's No. 2 producer after the U.S., and No. 3 Argentina to produce record crops to relieve the strain of tight global supplies." (Fletcher \& Day, january/2013)

“(...) Delays at Brazil's port are putting some grain-export contracts at risk. Sunrise Group, China's leading importer of soybeans, said Wednesday it will cancel an order to purchase about two million metric tons of Brazilian soybeans because of the delays." (Lewys, march/2013)

The above mentioned discussion is an illustrative example of the importance of operations strategy and the role of responsiveness on supply chain dynamics. The changes on Chinese strategy occur in a period of 2 months. Initially, China moved to South America suppliers counting on better quality and prices due to weather forecasts. However, critical issues on South American port infrastructure and delays put the business at risk. Consequently, in order to attend local market, China moved to a Japanese supplier. In spite of being more expensive, supply is more reliable.

This example can be initially observed through two different perspectives: The first one is related to customer perception of responsiveness and reliability and its impact on supply chain decisions. The second one considers the producer/manufacturer perception of responsiveness to address operations strategies. This study merges both perspectives in order to evaluate driving factors to decision-making process for new subsidiary location.

Firstly, this discussion demonstrates that international operations strategy, despite its similarity to local operations strategy, takes into consideration variables with different weights, such as legal requirements, cultural matters in personnel management, transport and cargo handling. According to Goldstucker (1965), until the 60s, the American multinational companies were still in their "infancy": they lacked guiding principles and there was an immediatist need to evaluate the profitability of international operations. In global terms, Christensen et al. (1987) identified that, in that period, such incentives did not necessarily lead organizations to continuation of the exportation process. In fact, then, many companies perceived export opportunities as incremental alternative sales potential, and not necessarily as a clear path committed to long-term business. In short, until that moment, the studies about internationalization had been limited to strategic questions of entry into a country, how to prepare executives to assume international positions, and the management of international costs (VILLAR and PAIVA, 2012). As of the 1980s, the "Asian Tigers" have emerged, and the perception that trade-offs (Skinner, 1969; Wheelwright, 1985) would gradually be substituted by cumulative competences (Ferdows \& Meyer, 1990, Noble, 1995; Flynn \& Flynn, 2004), and mass customization (Duray et al. 2000). In this period, a more meticulous exploration of the production chain and its subsystems was begun, evaluating the decisions for the location of manufacturing outside the country of origin (MEJIBOOM \& VOS, 1997), the different approaches according to different cultural perspectives (VOSS \& KATE, 1998) and the impact of these locational decisions on the firm's profitability (VOS, 1991). Secondly, operations strategy and supply chain strategy are close related (FROHLICH AND WESTBROOK, 2001; WONG, BOON-ITT AND WONG, 2011; SCHOENHERR AND SWINK, 2012).

Matson and McFarlane (1997) stated that responsiveness consists of the capacity for production to cope with possible disturbances in the process (inside or outside the organization) that may generate difficulties in achieving production goals. According to the authors, such disruptions could be because of unforeseen sales orders, machinery and equipment breakdowns, supply variations, logistics issues among others. In this understanding, Kritchanchai and MacCarthy (1998) argued that responsive manufacturing consists of factors that generate orders, not only in terms of time variations, but in seeking to understand the objectives of production time (agility and punctuality), as well as diversity. 
The responsive manufacturers are characterized by overcoming the competition based on five factors: a) development of products and processes; b) capacity of adaptation to environmental change; c) response to questions of uncertainty; d) efficiency in operations; and e) more and more global supply networks (SAAD and GINDY, 2007). Additionally, Kleindorfer (1993, 2004, 2007) studied valuable contributions to risk management in the supply area, illustrated various components of the optimization of risks in supply chains, the three outstanding ones being: (1) Hierarchies - relations that define supply chains with regard to the structuring of products, geography (location) and the priorities of the consumers; (2) Market mechanisms location of the markets, future market actions and auctions (forecast, collaboration, negotiating groups, among others), combinations of these factors or in isolation, will be able to attenuate risks in the chain by adequate combinations of strategic purchases from suppliers and long-term contracts; (3) Relations (business factors) between customers/ suppliers - based on incentives (negotiations) for instance, as the majority of the supply chains do not possess a single operator, but have several owners and decision-makers. Thus, it is understood that organizations must analyze the risks inherent to a lack of responsiveness in the chain, which could threaten an organization's business.

In sum, this study does not aim to advance risk management discussion. Instead, the assumption behind this research embraces the fact that lack of responsiveness is risky for the organization competitiveness. Consequently, in order to mitigate it, organization can consider disruption risk as one of the factors to be appraised during new subsidiaries location decision-making process.

\subsection{Driving-factors in the decision-making process for subsidiary location}

According to research by MacCarthy and Atthirawong (2003) about motivations that lead companies to take international locational decisions, five main factors were identified: cost factors; infrastructure; government characteristics and political and economic factors. Among other factors, some outstanding sub-factors are identified, such as the quality of the labor force; the existence of means of transport; quality and reliability of the means of transport; availability of labor; telecommunication systems; government stability; and laws governing industrial relations.
Equally, other factors relevant in international locational decisions were studied by Badri et al (1995); Hoffman and Schiniederjans (1994); Canel and Khumawala (1996) and Jungthirapanich and Benjamin (1995), whose research spanned the period 1875-1990. Their results showed that costs are prominent in international locational decisions, causing trade-offs in expenditures linked to social and political factors.Badri et al (1995) indicated global competition and economic factors as outstanding in determining location, including risks involving transport costs and climate.

However, despite being discussed in the literature about operations, the matter of responsiveness in the supply chain is a point that does not seem to be clearly established in the literature on internationalization as a motivational factor in the decision-making process for the establishment of international subsidiaries. Upon this discussion the following proposition emerges:

Proposition: In a decision-making process for new subsidiary location, supply chain responsiveness can be considered a key driving factor.

In order to address a deep analysis of this issue, a brief overview on internationalization strategy theories and RBV will be explored.

\subsection{Internationalization strategy theories}

Within the Uppsala theories, behavioral and cultural aspects are determinants of the internationalization process of companies. This process is formed of sequential steps dependent on knowledge companies acquire via the internationalization itself. Nevertheless, the belief of these theories is that a company's initial movement follows the direction of the nearby and/or neighboring countries, whether due to geographical or cultural aspects, or both.

Later, the theorists transformed the fundamentals of the Uppsala studies from the model of the firm to the relational (JOHANSON; MATTSSON, 1998; JOHANSON; VAHLNE, 2003b; HADLEY; WILSON, 2003), and, furthermore, some studies about the development of the subsidiaries in other countries (BIRKINSHAW, 1994; PATERSON; BROCK, 2002).

Other currents that ensued from Uppsala were the economic theories regarding the decisions taken by multinational subsidiaries abroad. These studies were founded on research by Coase (1937), with emphasis on the studies of transaction costs 
(WILLIAMSON, 1985; BUCKLEY; CASSON, 1981, 1998; RUGMAN, 1981; KOGUT, 1985).

The internationalization process of companies seen from the economic point of view seeks understanding of economic drivers associated to the companies' competitive advantages, known as the Eclectic Paradigm (DUNNING, 1980, 1988 and 1993). For the authors of this current of thought, the companies direct their activities to foreign markets based on three advantages: (a) ones specific to the company (structural or transactional); (b) those of location, linked to the places where operations are established in another country; (c) others specific to internationalization, based on the possibilities of asset transfer across national boundaries.

Dunning's $(1988,1993)$ thinking took into account the attempt to explain why American subsidiaries had lower performance than the parent companies, albeit higher than that of the local British competition. His theoretical model (denominated OLI - Ownership, Localization and Internationalization) considered that the differences in productivity were explainable by location (L), in part, by the specific property characteristics $(\mathrm{O})$, and by internalization actions (I) in the North American subsidiary.

In another study, Dunning (2001) explains key propositions of the Eclectic Paradigm related with international operations decisions regarding international production, and may be summarized as three sets of forces: (1) competitive advantages that companies of one nationality obtain over those of a different nationality, in the supply of markets or set of markets. This is based on the specific privilege of property $(\mathrm{O})$, or its capacity to co-ordinate assets that generate income so as to differentiate itself from the competition; (2) it becomes worthwhile to internationalize (I) markets to generate these assets and create added value to the products and/or services; (3) the location (L) chosen by the companies for their activities (operations) adding value beyond the national boundaries, ensuring that the competitive advantages are specific characteristics for each market/industry, region or country not permitting generalizations. The findings of the literature about internationalization strategies indicate that there are peculiarities in each way strategic decisions for international operations are adopted by companies.

Other issues concerning the internationalization of companies and production processes, originating from the 1990s, are related to the accelerated internationalization process of industries in terms of production, distribution and administration of goods and services. Such processes are understood according to 3 central aspects: increase in the direct external investment; decisive role of multinational groups as producers in the globalised economy; and the formation of networks of companies for international production (CASTELLS, 1999).

Cuervo-Cazurra (2008) argues that the difficulties in the internationalization processes vary: operational costs abroad; specific disadvantages of being foreign; subsidiaries tend to present worse results than those in the domestic markets; greater probability that the companies will close their subsidiaries than in the domestic market of origin; and frequently face litigation abroad. In this context, Fleury and Fleury (2009) discussed the existence of a need for a new reconfiguration of global production systems, especially for emerging countries. They affirmed that looking at internationalization strategies needs an understanding of how multinational companies are currently established, from which country to establish; which competitive advantages this country allows the new multinational company; which decisions about processes and operations make them more productive and profitable. In this regard, Egelhoff (1988) and Galbraith (2000) warn about new production structures, with varieties of processes linked to the systems or networks of global companies in terms of supply, as fundamental to internationalization.

The emergence of new internationalization models for multinational companies in these new economic powers has become evident, and the relation that triggers new processes of international operations, especially for decisions of international operations strategy that generate competitive advantages, until then not observed. Above all, a vast source of new studies and investigations about internationalization and operations could be developed in the next decades about emerging Latin American, African and Asian countries, among others.

The competitive advantages sought by companies verify alternatives as to how to process strategic operational decisions in a more productive manner in the face of transborder adversities. In the brief analysis developed, it is found that a significant part of the studies already developed are oriented towards multinational companies in already stable, wealthy economies, characterized by old companies, 
such as manufacturers in areas like vehicle assembly, information technology companies, parts/ equipment, food, among other economic sectors, in their domestic and internationalized markets.

In short, it can be perceived that, in matters regarding decisions for subsidiary location, Dunning's Eclectic theory takes into account four internationalization drivers: i) Resources (exploitation of natural resources and labor cost advantages); ii) Market (seeking locational advantage and synergy with the market); iii) Efficiency (seeking rationalization of production, local specialization and technology); and iv) Strategy (acquisition of strategic resources, whether competences or financial).

Complementarily, the Uppsala School remained focused on the behavioral and cultural aspects inherent to the internationalization process. Although both theories support the locational decisions regarding multinational subsidiaries, a gap appears: Will these theories be sufficient to take decisions about the location of international operations?

\subsection{Resource Based View (RBV)}

In the perspective of the resource-based view (RBV), a firm's resources or competencies are generally defined as all the assets, capabilities, processes and knowledge that reside in the firm (AMIT AND SCHOEMAKER, 1993 AND GRANT, 1991). These resources and capabilities can be viewed as bundles of tangible and intangible assets (DIERICKX AND COOL, 1989, BARNEY, 1991, 2001; PETERAF \& BARNEY, 2003). These resources and competence must meet the following conditions: i) the competence is difficult to imitate; ii) there is asymmetry among the firms with respect to ownership; iii) it must provide opportunities for the firm (COATES AND McDERMOTT, 2002).

Authors in the area of core competencehave proposed that competencies have strategic potential to exploit opportunities or neutralize threats from competitors and also give the firm the ability to obtain a near monopoly position in its chosen markets (RUMELT, 1984; PRAHALAD AND HAMEL, 1990).

Ramanujam and Varadarajan (1989) believe that RBV provides value-added theoretical explanations for the direction of a firm's diversification. "The direction of a firm's diversification is due to the nature of its available resources and the market opportunities in the environment" (MAHONEY \& PANDIAN, 1992).

Collis and Montgomery (1995) state that the strength of the RBV is the ability to explain, in clear managerial and practical terms, competitiveness, profitability and core competencies (PAIVA, ROTH, \& FENSTERSEIFER, 2008).

It is known that the dominance of climate, weather forecast and temperature cannot be held by the organization internally. But taking in consideration what RBV states, we can propose that the decisionmaking process and a search for the right location to establish their subsidiaries, taking into account climatic, geological and weather information is rather an internal organization choice. Thus, the combination of the available information, competent and updated people with the alignment of the organization's strategy and quick and wise decisionmaking process and units implementations, can be considered valuable resources, rare and difficult to imitate.

\section{RESEARCH METHODOLOGY}

As the research aim of this work referred to investigation of supply chain responsiveness as a possible decision driver for new subsidiary location, qualitative research of the exploratory type was considered the most suitable. This is due to the fact that this approach aims at providing greater familiarity with the problem so as to make it explicit or construct hypotheses (YIN, 2005, EISENHARDT, 1989).

Single case study research strategy is used when the focus is understanding of the dynamic present in specific places (EISENHARDT, 1989; VOSS et al., 2002). The case study is used when it involves deep exhaustive study of one or a few objects so as allow ample detailed knowledge (GIL, 1994), and is broadly used with the aim of investigating how and why certain phenomena occur (YIN, 2005). The use of case study methodology in qualitative research has been driven by the Operational Management study field, as it is an approach that allows great proximity and deep understanding of the phenomenon under study (MEREDITH et al., 1989; MCCUTCHEON; MEREDITH, 1998; LEWIS, 1998; VOSS et al., 2002).

With the aim of maintaining methodological rigor, the study was based on the research processes 
proposed by Eisenhardt (1989) and Stuart et al. (2002) that involve: i) definition of the research question; ii) selection of the case(s)/population; iii) construction of the research instruments and protocols; iv) field research/data collection; v) data analysis and formulation of hypotheses; vi) closure and dissemination (EISENHARDT,1989; STUART; ET AL. 2002; SEURING, 2008).

Besides, in order to assure the quality of case study development, authors care of following appropriate criteria (EISENHARDT,1989; MILES \& HUBERMAN, 1994; YIN, 2005): i. internal validity (the degree to which findings correct map the phenomenon); ii. external validity (the degree to which finds can be generalized to other contexts); iii. reliability (the extent to which it can be replicated by another researcher) and iv. Objectivity (the extent to which findings are free from bias).

The criterion of selecting the case was based on its intensity (Miles \& Huberman, 1994). It means authors search for "information-rich cases that manifest the phenomenon intensely, but not extremely" (p.28). The case selected is one of the largest world organizations in the agribusiness industry.

The data collection process employed multiple methods. Yin's (2005) three data collection principles were followed: i) use of multiple evidence sources; ii) creation of a case study database; iii) maintenance of the interlinkage of evidence. The main advantage presented by multiple evidence is the development of converging lines of investigation, making the final information more structured and robust (YIN 2005). For principle number one, data triangulation was taken as the base, in the second, data collection or evidentiary base, and, in number three, for the interlinkage of evidence, the sequence of forensic evidence was adopted, taken from the report established in the data collection, supported by evidentiary citations from the literature and responses in interviews. All interviews were transcribed by the authors as well as nonparticipant observation (visits and interviews in loco at the company's operational unit, during the first semester of 2012).

Thus, the data collection and evidence from various sources (semi-structured interviews of the organization's executives and specialists on the theme, field notes, documents, reports, and notes for the press divulgated on the organization's site, news in newspapers and professional journals, academic articles and observation notes taken by the researchers) comprise the full database for analysis. This database offered the opportunity of data triangulation and support for the research discoveries.

The criterion of selecting respondents followed initially by hierarchical level and it was validated during interview process. Further, authors adopt snowball strategy asking the current respondent to indicate a person to continue the interview or someone who should answer pending questions/ issues. Sample included a broad extend of levels since top managers, as the Chief Executive of International Operations till operational functions. Interviews were conducted on site, except one which was by telephone (due to unavailability of respondent). It includes the visit on three conventional sites and a brand new and high tech plant (inaugurated on 2009). This strategy reveals the fifth criteria of robustness of the present study: its authenticity. Authenticity criteria is inspired on ethnographic studies and it aims to assure the degree of engagement of researcher on field. It reveals that the researcher was there, collected data by itself reflecting a genuine experience in writing up findings. According to Pozzebon (2004), the nuances that differ it from ethnographic study consists that researchers interacted "with actors who are deeply immersed in the field."

After the data collections, they were consolidated, categorized and discussed by the authors. Further, one of the authors returned to the field and retrieve database to evaluate pending points. Complementarily, it was decided to make a new review and analysis of the literature, with the aim of deepening and verifying the adherence of the case study to the theoretical models used in this research. In sum, such efforts aim to achieve rigorous links between the data collection, analysis and specific content focused on the research, as well as it enhanced the reliability of database.

\section{THE COMPANY "D" CASE - PRESENTATION AND DISCUSSION}

Company " $\mathrm{D}$ " employs around 160 thousand and is present in over 65 countries on all the continents. Its annual revenue is approximately US\$ 120 million. Established in 1865 in the USA, it is founded on three principle competences: supply chain management, risk management, development 
and research. Its business activities include the purchase, processing and distribution of grains and other agricultural commodities, the manufacture and sale of animal feed, ingredients for processed foods, pharmaceutical products and consumer goods and food production. It also operates a large financial services branch, which manages the risks for agribusiness firms in the commodities markets.

Due to the market volatility, the Company " $\mathrm{D}$ " group has, for years, developed and constructed its own methodology for risk management, capable of measuring and controlling its exposure. This competence, so important for the company, has ended up being transformed into a service it commercializes globally. This capacity for measuring and managing risk is due to the fact the corporation's main aim is to honor its commitments and become a reliable stable supplier, a characteristic peculiar to the majority of the actors in this sector, given it is subject to unforeseeable events, such as the vagaries of climate and commodity price fluctuations. In 2003 , it transferred part of its financial operations to a hedge fund with around US $\$ 10$ billion in assets and liabilities.

The Eclectic Paradigm is clearly observed in the first steps adopted in the international operations strategy of Company " $\mathrm{D}$ ". More specifically, the group appears to adopt and readapt the operations strategies over time due to the dynamic environment (economic and social). Initially, the company adopted a posture of seeking a market. This first phase in the process occurred at the end of the 1920s, establishing its first sales offices outside the USA in Montreal, Canada, in 1928, and in Geneva, Italy, in 1929.

As of the 1930s, the company grew, opening new offices in Winnipeg (Canada), Rotterdam (Holland) and Buenos Aires (Argentina). During and soon after the 2nd World War, a major supply crisis ravaged the world (Churchill, 1983; Hamilton, 1983). This step redirected the decision-making process of the organization, instead of just the market, the company follows a new strategic direction: seeking the best places for production and world supply. The Latin American offices were reopened, and, as of the 1940s, land acquisitions for cultivation were begun all over the world, mainly in Latin America, Europe and Asia, as a consequence of the migratory process of Europeans to North America (Rystad, 1992).

After the destabilization of world supply caused by the 1970s Oil Crisis, when the price per barrel rose over $400 \%$, directly impacting the major world economies (Hamilton, 1983), a new strategic direction emerged for Company " $\mathrm{D}$ ". It would grow faster, acquiring companies as an alternative to expanding its branches and its world presence. For example, in 1964, the organization entered the European market with the acquisition of a large Dutch grain organization.

According to Dunning (1988), in the Eclectic Paradigm, there are four locational drivers, especially with regard to the acquisition of strategic resources, where Company " $\mathrm{D}$ ", as of 1980, after acquisitions and mergers, began to prioritize organizational efficiency. At the time, the organization began an enormous rationalization exercise and sought this through productive efficiency, perceived through the eminent interest of the group in acquiring fertilizer besides this, the 1990s were marked by the establishment of various quality assurance programs, which were also directly related to waste control and an increase in productivity of their farms and world processing.

However, Company "D" developed a new approach to the operations strategies as a competitive advantage. As the organization's main strategy of internationalization, global strategies, adapting to the multi-domestic strategy with a focus on new business opportunities in the agribusiness segment. The emphasis on the strategy is to provide the company with operations with an acceptable degree of autonomy for the local realities, through interdependence of plants, targeting new customers and new markets, following the group's own ethical principles in all its businesses.

At the end of 2011, it acquired the largest animal feed company in the world, a business worth U\$ 2.1 billion, operating 87 plants in 30 countries (its parent company being located in Holland), with a strong tradition of producing at high standards and with international certification in the segment. Such a strategy of acquisition has made Company " $\mathrm{D}$ " aggregate its complementary operations/activities in composite feed for animals in the entire global supply chain, its risk management, in addition to expertise, technology, additives, pre-mixtures and ingredients in the global production related to animal feed.

It is observed that Company " $\mathrm{D}$ ", occupies a position that is a consequence of the adoption of 
evolutionary forms of strategy, which, over the years, adapted to the environment which it was situated and the opportunities. Thus, the first exercises of internationalization were developed through the search for new markets, followed by the postWar period and the search for natural resources. Next, new internationalization strategies took into account efficiency in the rationalization of costs and scale economies, and, finally, the acquisition of new global portfolios. However, it is perceived that the latest actions performed by Company " $\mathrm{D}$ " go a little beyond the simple search for strategic assets and new business. As of the 2010s, the organization's focus was redirected to a new level, previously unexplored in the literature on international location decision-making.

The market, in which the corporation is involved, perhaps by being a monopolized environment, is characterized by the domination of large organizations. And the questions of commitment to delivery on time have always been considered "unforeseen", easily justified by climatic variations, for example. The fact is that Company " $\mathrm{D}$ " began to perceive that if it improved its level of services for its clients, it could gain a significant competitive advantage over its competitors.

For such, the company decided to internationalize, seeking different latitudes, thereby mitigating possible climatic risks that always used to impact the business (the whole agribusiness sector) and guaranteeing a more continuous and fluid supply to the market.

Chart 1: Company "D" Performance in South Africa

\begin{tabular}{|c|c|}
\hline Year & $\begin{array}{l}\text { Investments made and observations about locational decisions, } \\
\text { responsiveness and risks. }\end{array}$ \\
\hline 1981 & $\begin{array}{l}\text { Company " } \mathrm{D} \text { ", starts operations in the country, incorporating a } \\
\text { large international operations company, with an office in } \\
\text { Johannesburg, the goal being to develop activities in southern Africa. }\end{array}$ \\
\hline 1983 & Installation in the country of a seed production plant in Potchefstroom. \\
\hline 1988 & $\begin{array}{l}\text { The company faces difficulties in its operations due to the apartheid } \\
\text { regime, particularly due to international sanctions. }\end{array}$ \\
\hline 1994 & $\begin{array}{l}\text { Re-establishes operations in the country, at its head office in } \\
\text { Johannesburg, with financial negotiations, but, in particular, with } \\
\text { agricultural commodities, production, research, and seed sales. }\end{array}$ \\
\hline 1997 & $\begin{array}{l}\text { Acquires seed plant in Carnia (production, commercialization } \\
\text { and sale of corn - white and yellow - sorghum, sunflower and } \\
\text { hybrid wheat. }\end{array}$ \\
\hline
\end{tabular}




\begin{tabular}{|c|c|}
\hline 1998 & $\begin{array}{l}\text { Sells seed operations in Carnia to a large multinational in the } \\
\text { sector (specialized), fulfilling strategic decisions to internationalize } \\
\text { at global level. }\end{array}$ \\
\hline 2004 & Implements significant risk management businesses. \\
\hline 2006 & $\begin{array}{l}\text { Acquires cotton seed removal companies in the southern African } \\
\text { region, with investments to provide greater variety, quality and } \\
\text { availability of the product, establishing a differential in the market. }\end{array}$ \\
\hline 2009 & $\begin{array}{l}\text { Broadening of business to cover oilseeds and grains, for direct } \\
\text { origination with the opening of offices in Kimberley and Delmas. }\end{array}$ \\
\hline 2010 & $\begin{array}{l}\text { The companies announce expansion of their grain origination } \\
\text { operations in the country, with offices in Welkom, Hope Town and } \\
\text { Lichtenburg. (Establishment of its own operations in the country). }\end{array}$ \\
\hline 2011 & $\begin{array}{l}\text { Expansion of the business of grain origination, with the opening of } \\
\text { a new office in Belem, with the transfer of the former office in Welkom } \\
\text { to Wesselsbron. It also assumes a position in the market responsible } \\
\text { for sugar distribution in the country and its neighbors. }\end{array}$ \\
\hline
\end{tabular}

Source: the Company “D” site and CEO interview - organized by the authors.

Thus, Company "D" set up operations in South Africa, its new activity base, the main decision strategy being to assume global leadership in the animal feed sector, contemplating other productive chains in which the company already had significant leadership and interdependence, taking advantage of favorable climatic conditions, and an increase in the capacity to develop new products and services.

Reinforcing the theoretical analyses of the internationalization strategies of the Eclectic Paradigm, Dunning(1988),regardinglocationd rivers, the questions of responsiveness (MACCARTHY; ALTTHIRAWONG, 2003; MATSON; McFARLANE, 1997) and risk management (KLEINDORFER, 19981999; COHEN; KUNREUTHER, 2007), Company " $\mathrm{D}$ " adopted as investments in South Africa the performance demonstrated in Chart 1 :

According to information obtained in the CEO interview, Company " $\mathrm{D}$ " could attend other, already established customers, dealing with minimization of their risks related to costs, climatic factors, global economic fluctuations in other activity segments, increasing the scale and focus of its operations, making it the absolute leader in the segment. Its competitors that have difficulty in imitating its actions and reaching the level of service it is offering on the African continent in different locations.

Upon on that, it can be perceived that the literature on internationalization did not fully involve the variable responsiveness, opening up the possibility of introducing this variable in a more contemporary model of locational decision-making in new international operations. The illustrative model that summarizes the evolution of the strategies of operation and location of subsidiaries adopted by Company "D" (analyzed by the Eclectic Paradigm) is presented in Figure 1. 


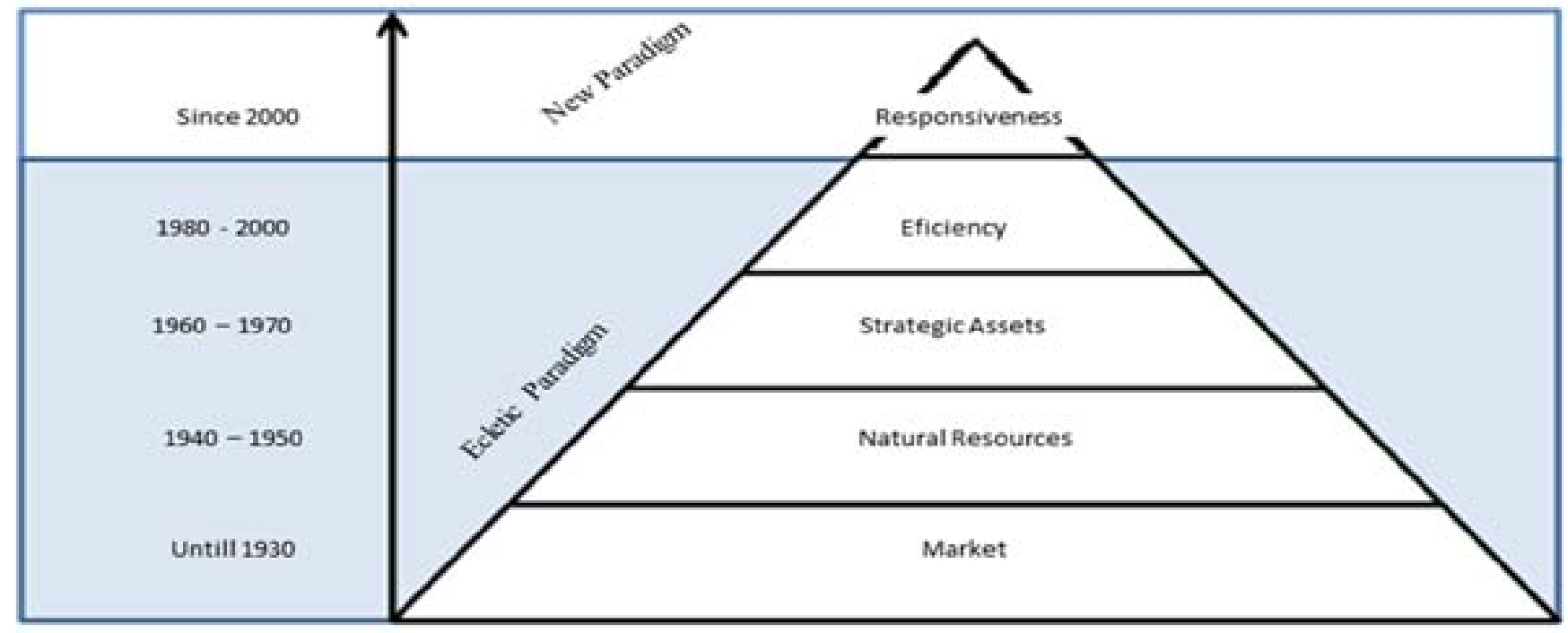

Figure 1: International operations and location of subsidiaries adopted by Company “D” Source: Developed by authors

In the next section we address the final considerations, limitations of this study and possible new research avenues.

\section{FINAL CONSIDERATIONS}

The main objective of this study was to explore if the degree of responsiveness in the supply chain influences decisions regarding the location of multinational subsidiaries. It led to a case study of a multinational enterprise, one of the largest world organizations in the agribusiness industry, and assessment of the recent strategies adopted by it in the definition of new subsidiaries. Authors adopt single case study strategy because it permits "conceptual refinements with higher level of validity over a smaller number of cases" (George and Bennett, 2004). The decision of selecting the case was based on its intensity (Miles \& Huberman, 1994).

In the same way, the in-deep case analysis has some implications: It was possible to identify that a decision was taken by the organization due to the need to be responsive to its customers, a critical characteristic in the sector in which it is engaged, principally due to climatic risks that can directly impact supply. Thus, the organization that had already developed advanced responsiveness competences, decided to broaden its international manufacturing network, seeking countries across various latitudes to encompass different climatic and other natural conditions to the benefit of its soya, cocoa and cotton production.
As climate changes are determinant for productivity in some specific production systems like agribusiness and commodities, the decisionmake process for establishing new production subsidiaries is supposed to consider different weather and geography environment. One cannot change the external environment but, can spread subsidiaries in different latitudes in order to exploit natural resources available all year long. In the "big picture" the organizations able to combine, absorb and align available information and knowledge are able to take decisions in order to build a specific asset (subsidiary location) which is valuable and

Figure 1 was presented as a possible path estimated for the internationalization process of companies with more active participation in the operations strategy. However, this model cannot be generalized at the moment, since it has been extracted from a single case study. Nevertheless, it does offer important insights, and, based on this proposition, quantitative studies of companies could be developed so as to observe whether generalization is possible.

The limitation of the present study also includes a possible bias on case selection, which limits the possibility of generalization. However, building upon a logical chain of evidences, it was possible to identify patterns that suggest an important characteristic in the decision-making process. The factor that drives company $\mathrm{D}$ to establish the subsidiary in Africa (responsiveness) has a quite novel role and was not clearly explained by the main 
theoretical currents of company internationalization (neither in OM nor IB literature).

An avenue of opportunities emerges from this, the aim being to deepen discussion raised by this work. Various approaches can be directed, whether through multiple case studies of organizations with diverse profiles and in different sectors (EISENHARDT and GRAEBNER, 2007) in order to observe the phenomenon in all its complexity and diversity, whether via quantitative research or even event study.

\section{REFERENCES}

Arrow, K.J.; Kurz, M. Public Investment, The rate of return, and optimal Fiscal policy. Baltimore, The Johns Hopkins Press, 218p, 1970.

Barney, J. (1991). Firms resources and sustained competitive advantage. Journal of Management, 17(1), 99-120.

Barney, J. (2001). The resource-based view of the firm: Ten years after 1991. Journal of Management, 27(6), 625-641.

Bartlett, C. A.,; Goshal, S. Going Global - Lessons from Late Movers. Harvard Business Review, 2000.

Bazerman, Max H. Processo decisório: para cursos de administração e economia. Rio de Janeiro: Elsevier, 2004.

Bergamini, S. Controles Internos como um Instrumento de Governança Corporativa. Revista do BNDES; Rio de Janeiro: v. 12. São Paulo, Dez/2005.

Berstein, P.L. Desafio aos deuses: a fascinante história do risco; Trad. Ivo Korlowski - Rio de Janeiro: Elsevier, 1997.

Buckley, P.J., Casson, M.C. Analyze strategies Input Market: Extending the Approach Internalisation. Third Quarter, Vol. 29 no 3, 1998.

Buckley, P.J., Dunning, J.H., \& Pearce, R.B. 1977. The influence of firm size, sector, nationality, and degree of multinationality in the growth and profitability of the world's largest firms', Weltwirtschaftliches Archiv, 114: 243-257.

Canel, C.; Khumawala, B.M. A mixed-integer pro- gramming approach for the international facilities location problem. International Journal of Operations \& Production Management, vol. 16 no 4, 1996, pp. 49-68.

Castells, M. A Sociedade em redes. Trad.: Roneide Venancio Majer. 6. Ed. São Paulo e Terra, 1999.

Chirstensen, C.H., Rocha, A., Gertner, R.K. An empirical investigation of the factors influencing exporting success of Brazilian firms. Journal of International Business Studies, p. 61-77, 1987.

Churchill, W. The Second World War. Boston: Houghton Mifflin, 1983.

Clemen, R.T., Reilly, T. Making Hard Decisions, Duxbury, 2001.

Coase, R. H. The Nature of the Firm. Economica. The London School of Economics and Political Science., New Series, Volume 4, Issue 16 (Nov., 1937), $386-405$.

Coates T.T., McDermott C.M. An exploratory analysis of new competencies: A resource based view perspective (2002) Journal of Operations Management, 20 (5) , pp. 435-450.

Cohen, M.A., Kunreuther, H. Operations Risk Management: Overview of Paul Kleidorfer's Contribution. Production and Operations Management Society, 2007.

Collins, J.M. A Market performance comparison of US firms active in domestic, developed and developing countries. Journal of International Business Studies. 2: 271-287, 1990.

Cuervo - Cazurra, A. The internationalization of developing countryMNEs: thecaseofMultilatinas. Journal of International Management, v. 14, n. 2, p. 138-154, 2008.

Damodaran, A. Gestão estratégica do risco: uma referência para a tomada de riscos empresariais. Trad. Felix Nonnenmacher - Porto Alegre: Bookman, 2009.

Dunning, J. Towards and eclectic theory of interna tional production: some empirical tests. Journal of International Business Studies, 11 (Spring), pp. 9-31, 1980.

Dunning, J. The Theory of International Production. 
The International Trade Journal, vol.III, n. 1, p. 21-66, Full 1988.

Dunning, J. Multinational enterprises and the global economy. Workhingan: Addison-Wesley, 1993.

Dunning, J. The Eclectic (OLI) Paradigm of International Production: Past, Present and Future. International Journal of the Economics of Business, vol. 8 (2) p.173-190, 2001.

Dunning, J.; Lundan, S. M. Institutions and the OLI paradigm of the multinational enterprise. Asia Pacific J. Management, 25: 573-593, 2008.

Duray, R., Ward, P.; Milligan, G.; Berry, W. L. Approaches to mass customization: configurations and empirical validation. Journal of Operations Management, 18, pp. 605-625, 2000.

Egelhoff, W. Strategy and structure in multinational corporations: a revision of the Stopford and Wells model. Strategic Management Journal 9, 1-14,1988.

Eisenhardt, K., Graebner, M. Theory building from cases: opportunities and challenges. Academy of Management Journal, Vol. 50, p. :25-32, 2007.

Eisenhardt, Kathleen M. Agency theory: an assessment and review, Academy of Management, 1989.

Ferdows, K., Meyer, A. Lasting Improvements in Manufacturing Performance: In Search of a New Theory. Journal of Operations Management, 9 (2), 168-184, 1990

Fletcher, O., \& Day, M. (Jan/13/ 2013). The Wall Street Journal: http://goo.gl/jJghr, Acessed March, 25th 2013.

Fleury, A.; Fleury, M. T. Understanding the strategies of late-movers in International Manufacturing. International Journal of Prodution Economics ,122, pp. 340-350, 2009.

Flynn, B. B.; Flynn, E. J. An exploratory study of the nature of cumulative capabilities. Journal of Operations Management , 22, pp. 439-457, 2004.

FMI (2011). Disponível em < http://goo.gl/vwFNN > acessado em 12/02/2012.
Freitas, C.M.; Gomez C.M. Technological risk analysis from the perspective of the social. História, Ciências, Saúde - Manguinbos, vol. III (3): 485-504,1997.

Frohlich M.T., Westbrook R. Arcs of integration: An international study of supply chain strategies (2001) Journal of Operations Management, 19 (2) pp. 185-200.

Galbraith, R. W.; Kolesar, M. B. A services-marketing perspective on e-retailing: implications for e-retailers and directions for further research. Internet research, vol.10. Iss 5, pp. 424-438, 2000.

Gil, A.C. Como Elaborar Projetos de Pesquisa. São Paulo: Atlas, 1994

Goldstucker, J. L. Allocating Costs in International Operations. Business Horizons , pp. 75-84, 1965.

Guillen, M. F.; Garcia-Canal, E. The American Model of the Multinational Firm and the "New" Multinationals from Emerging Economies. Academy of Management Perspectives, pp. 2335, 2009.

Hamilton, J. D. Oil and the Macroeconomy since World War II. Journal of Political Economy, 91 (2), pp. 228-248, 1983.

Hammond, J.S., Keeney, R.L., Raiffa, H. Decisões inteligentes: somos movidos a decisão - como avaliar alternativas e tomar a melhor decisão. Rio de janeiro: Elsevier, 2004.

Johanson, J.; Mattsson, L.G. Internationalization in industrial systems: a network approach. In: HOOD, N.;VAHLNE, J.E. (ed). Strategies in global competition. New York: Croom Helm, 1988.

Johanson, J.; Vahlne, J.E. The Internationalization Process of the Firm - a model of Knowledge Development and Increasing Foreign Market Commitments. Journal of International Business Studies. Spring/Summer, Vol. 8 Issue 1, p. 25-34, 1977

Johanson, J.; Vahlne, J.E. Business Relationship Learning and Commitment in the Internationalization Process. Journal of International Entrepreurship 1, 83-101, 2003.

Johanson, J; Vahlne, J.E. Building a model of firm internationalization. In: BLOMSTERMO, 
A.; SHARMA, D. (ed) Learning in the internationalisation process of firms, 2003a.

Johanson, J; Vahlne, J.E. Business relationship Learning and commitment in the internationalization process. Journal of International Entrepreneurship, v. 1, n. 1, p. 83101, 2003b.

Johanson, J.; Wiedersheim, P.F. The internationalization of the Firm. Four Swedish Cases. Journal of Management Studies, p. 305-322, 1975.

Jorion, P. Value - at - Risk: A nova fonte de referência para a gestão do risco financeiro. BM\&F, 2003.

Kleindorfer, P.; Saad, G. Managing disruption risks in supply chains. Production and Operations Management, Vol. 14, pp. 53-68. 2005.

Kogut, B. Designing Global Strategies: Comparative and Competitive value - added Chains. Sloan Management Review. 26 (4) pp. 15 - 28, 1985.

Kouvelis, P.; Chambers, C.; Wang, H. Supply Chain management Research and production and Operations Management: Review, Trends, and Opportunities. Production and Operations Management. 2006.

Kritchanchai, D.; Maccarthy, B.L.Responsiveness and strategy in manufacturing. Proceedings of workshop responsiveness in manufacturing, $\mathrm{n}$. 98/213 IEE, London, 1998.

Lewis, M.W. Iterative triangulation: a theory development process using existing case studies. Journal of Operations Management, v. 16, n. 4, p. 455-469, 1998.

Lewys, J. (03/21/2013). Brazilian Government, Unions in Talks to Avert Port Strike. The Wall Street Journal: http://goo.gl/VlCHQ. Accessed 03/25/2013.

Mahoney, J. T., \& Pandian, J. R. (1992). The Resou-rce-Based View within the conversation of Strategic Management. Strategic Management Journal, 13(5), 363-380.

MacCarthy, B. L.; Atthirawong, W. Factors affecting location decisions in international operations - a Delphi study. International Journal of Operations Managemenet. Vol.
March, J.G., Shapira, Z. Managerial Perpsective on Risk and Risk Taking. Management Science, vol.33, № 11 pp- 1404-1418, 1987.

Matson, J. B.; McFarlane, D. C. Assessing the responsiveness of existing production operations. International Journal of Operations \& Production Management, 19 (8), 765-784, 1999.

McFarlane, D., Matson, J. Tolls for Assessing the Responsiveness of Existing Production Operations. In: Proceedings of IEE Workshop, Responsiveness in Manufacturing, London, 1998.

Mccutcheon, D.M., Meredith, J.R. Conducting case study research in operations management. Journal of Operations Management, v. 11, n. 3, p. 239-256, 1993.

Mejiboom, B.; Vos, B. International manufacturing and location decisions: balancing configuration and co-ordination aspects. International Journal of Operations \& Production Management , 17 (8), pp. 790-806, 1997.

Meredith, J.R., Raturi, A., Amoako-Gyampah, K., Kaplan, B. Alternative research paradigms in operations. Journal of Operations Management, v. 8, n. 4 , p. 297-326, 1989.

Miles, M. B., Huberman, A. M. Qualitative Data Analysis. 2nd edition. California: Sage Publications, 1994.

Noble, M. Manufacturing strategy: testing the cumulative model in a multiple country context. Decision Sciences , 25 (5), 693-721, 1995.

Paiva, E., Roth, a, \& Fensterseifer, J. (2008). Organizational knowledge and the manufacturing strategy process: A resource-based view analysis. Journal of Operations Management, 26(1), 115-132. doi:10.1016/j.jom.2007.05.003

Paterson, S.L., Brock, D.M. The development of subsidiary-management research: review and theoretical analysis. International business review, vol.11, issue 2, p. 139-163, 2002.

Peteraf, M. a., \& Barney, J. B. (2003). Unraveling the resource-based tangle. Managerial and Decision Economics, 24(4), 309-323. doi:10.1002/mde.1126

Pozzebon, M., Freitas, H.M.M. Pela aplicabilidade com um maior rigor científico - dos estudos de 
caso em sistemas de informação, Revista de Administração Contemporânea, vol.2, n.2, p. 143-170, 1998.

Ramanujam, V. and P. Varadarajan. 'Research on corporate diversification: A synthesis', Strategic Management Journal, 10, 1989, pp. 523-551.

Rystad, G. Migration, Immigration History and the Future of International migration. International Migration Review , 26 (4), 1168-1199, 1992.

Rugman, Alan M. Inside the Multinationals. International business enterprises - Economic aspects. Croom Helm Ltd, 2-10 St John's Road, London. British Library Cataloguing in Publication Data (1981).Web version available in: www.books.google.com. Acesso em 20/05/2011.

Saad, S.M., Gindy, N.Z. Future Shape of the responsive manufacturing enterprise. Benchmarking An International Journal. Vol. 14, no1, pp. 140-152, 2007.

Schoenherr T., Swink M. Revisiting the arcs of integration: Cross-validations and extensions (2012) Journal of Operations Management, 30 (12), pp. 99-115.

Seuring, S.; Muller, M. From a literature review to a conceptual framework for sustainable supply chain management. Journal of Cleaner Production. Vol. 16 (15), p 1699-1710, 2008

Skinner, W. Manufacturing - missing link in corporate strategy. Harvard Business Review, 47 (3), pp. 136-145, 1969.

Stuart, I., Mccutcheon, D., Handfield, R., Mclachlin, R., Samson, D. Effective case research in operations management: a process perspective. Journal of Operations Management, v. 20, n. 5, p. 419-433, 2002.

Svensson, G. A conceptual framework for the analysis of vulnerability in supply chains. International Journal of Physical Distribution \& Logistics Management, v. 1, 2000.

Tang, C.S. Perspectives in supply chain risk management. International Journal of Production Economics. 01/2006.

UNCTAD. World Investment Report. Nova Iorque: United Nations, 2010.
Villar, C., Paiva, E.L. Estratégia de Operações Internacionais: Evolução e Tendências, Revista de Administração da Unimep v. 10, p. 1-27, 2012.

Vos, G. C. A Production-allocation approach for international manufacturing strategy. International Journal of Operations \& Production Management,11(3), 125-134, 1991.

Voss, C.; Kate, B. Differences in manufacturing strategy decisions between Japanese and Western manufacturing plants: the role of strategic time orientation. Journal of Operations Management, 16, pp. $147-158,1998$

Voss, C.A., Tsikriktsis, N., Frohlich, M. Case research in operations management. International Journal of Operations \& Production Management, v. 22, n. 2, p. 195-219, 2002.

Wiedersheim, P.F.; Olson, H.C.; Welch, L.S. Pre-export activity: the first step in internationalization. Journal of International Business Studies, 1978.

Welch, L.; Luostarinen, R. Internationalization: Evolution of a concept of General Management, 14 (2): 34-55, 1988.

Wheelwright, S. C. Manufacturing Strategy: Defining the Missing Link. Strategic Management Journal, 5 (1), pp. 77-91, 1984.

Wheelwright, S.; Hayes, R. Competing through manufacturing. Harvard Business Review, pp. 99-109.

Williansom, O.E. The Economics Institutions of Capitalism. Capítulo 1, London: The Free Press, 1985.

Wong C.Y., Boon-Itt S., Wong C.W.Y. The contingency effects of environmental uncertainty on the relationship between supply chain integration and operational performance (2011) Journal of Operations Management, 29 (6) , pp. 604-615.

Yin, R. K. Estudo de Caso: planejamento e métodos. Trad. Daniel Grassi. 3 $3^{\mathbf{a}}$ ed. Porto Alegre: Bookman, 2005.

Yin, R.K. Estudo de Caso: planejamento e métodos. 4. Ed. - Porto Alegre: Bookman, 2010. 


\section{AUTHOR'S BIOGRAPHY}

Ronald Pires Tavares da Silva: PhD Candidate at UNISINOS-RS Brazil and professor at the State University of Mato Grosso do Sul. Graduated in Business Administration at School of Accounting and Administrative São Judas Tadeu (1988), Strategic Planning Specialist (ULBRA) and Marketing (ESPM), Master in Business Administration from the Federal University of Santa Catarina (2001). Experience in marketing and business strategy - consulting and training. Research on international agribusiness and corporate strategy.

Cristiane Biazzin Villar: PhD candidate in Business Administration (Fundação Getulio Vargas - EAESP São Paulo - Brazil). Her previous background includes 18 years' experience as Operations and Supply Chain Executive in multinationals enterprises. Her research interests are: supply chain management, buyer-supplier relationships, operations strategy and manufacturing network.

Janaina Siegler: PhD candidate in Operations Management at FGV-SP and visiting Scholar at Indiana University, IN-USA. Master (FEARP/USP 2009) and College (UFU-1997) still in Management field. Experience as entrepreneur, consulting and professor in Higher Education (undergraduate and post-graduate). Research interests in Value Creation, Buyer Supplier Relationships and Behavioral Operations. 